\title{
NOTES
}

\section{A COMPARISON OF LOWER AND HIGHER PLANTS AS ACCUMULATORS OF RADIOACTIVE FALL-OUT ${ }^{1}$}

\author{
Eville Gorham
}

In an earlier paper (1) accumulation of radioactive fall-out by plants in the English Lake District was related to the mineral content of the various species, with both mosses and angiosperms low in mineral ash showing much more radioactivity than plants of high mineral content in the same groups. The present study compares radioactivity of ash from lichens, mosses, and angiosperms, using some of the data previously employed, plus counts for three lichens made toward the end of the work already reported.

The plants were collected in early 1958. Samples were dried at 105 to $110^{\circ} \mathrm{C}$ and ashed at bright-red heat. Aliquots of about $50 \mathrm{mg}$ ash were fixed in planchets with "Celloidin" and tested within three days of collection for radioactivity, in a lead tower with CV 2139 counter tube (end-window weight $2.3 \mathrm{mg} / \mathrm{cm}^{2}$ ). At least 1000 counts were recorded for each sample on a "Panax 44A" scaler. Background counts, averaging 8 per minute, were measured daily and subtracted from those shown in Table I and Fig. 1.

TABLE I

Radioactivity in angiosperms, mosses, and lichens of comparable ash content

\begin{tabular}{|c|c|c|c|c|c|}
\hline $\begin{array}{l}\text { Number } \\
\text { of } \\
\text { samples }\end{array}$ & Type of plant & $\begin{array}{l}\text { Log \% osh } \\
\quad \pm \text { S.E. }\end{array}$ & $\begin{array}{l}\text { Log c.p.m.* } \\
\quad \pm \text { S.E. }\end{array}$ & $\begin{array}{l}\text { Antilog } \\
\% \text { ash }\end{array}$ & $\begin{array}{l}\text { Antilog } \\
\text { c.p.m. }\end{array}$ \\
\hline 10 & Angiosperms & \multirow{3}{*}{$\begin{array}{r}0.6606 \\
\pm 0.0652 \\
0.6619 \\
\pm 0.0493 \\
0.6536 \\
\pm 0.1024\end{array}$} & \multirow{3}{*}{$\begin{array}{r}1.800 \\
+0.154 \\
2.183 \\
\pm 0.092 \\
2.263 \\
\pm 0.168\end{array}$} & 4.58 & 63 \\
\hline 20 & Mosses & & & 4.59 & 152 \\
\hline 3 & Lichens & & & 4.50 & 183 \\
\hline
\end{tabular}

*Counts per minute for $50 \mathrm{mg}$ ash.

No correction for self-absorption was applied, nor were the isotopes involved identified; so that the results merely give an arbitrary comparison of total activity under standard conditions. To give some crude comparison with a radioactive standard, counts were made of weights of potassium iodide similar to the weights of plant ash used. This salt contains about the same percentage of potassium as many plant ashes, and $50 \mathrm{mg}$ yielded an average count rate of about 4 per minute, after subtraction of the background rate.

Table I summarizes the data for the various types of plant. In calculating the average values a logarithmic transformation was employed in order to

${ }^{1}$ This work was carried out while the author was on the staff of the Freshwater Biological Association, Ambleside, England.

Can. J. Botany. Vol. 37 (1959) 
bring the frequency distributions closer to the normal; and it will also be noticed that the ash contents of the three groups of plants were selected to be closely similar, thus minimizing the influence of ash content on count rate and emphasizing the effect of plant type.

A considerable difference is apparent in the radioactivity of the lower and higher plants, with the angiosperms exhibiting a mean (antilog) count rate of only 63 per minute in comparison with mean (antilog) rates of 152 and 183 for the mosses and lichens respectively. The difference between the log means for angiosperms and mosses is significant at the $5 \%$ level, that between mosses and lichens is quite insignificant. Separation of the 20 moss samples into species of woodland or semi-aquatic fen habitats, or into Sphagnum and other species, reveals little difference between these categories. The absence of any marked difference between the count rates of terrestrial woodland and semi-aquatic fen mosses suggests that fall-out is strongly held by the vegetation and not leached extensively from the wooded slopes into the wet and peaty valley bottoms. In this connection it may be noted that the plant ashes exhibited 23 times the radioactivity of ashes from evaporated stream waters (1).

Although no conclusive explanation for the greater radioactivity of the lower plants can be offered at this time, it may be presumed that they have a greater surface area per unit dry weight of tissue, and this should aid them not only in trapping particulate fall-out but also in absorbing the components soluble in surface runoff. Their habits of growth, as mats or cushions on the soil surface, should also enhance their ability to accumulate fall-out materials from runoff (cf, 3).

The decay of the radioactivity in these plants is illustrated in Fig. 1, where count rates of a sample of Sphagnum papillosum ash are plotted on a logarithmic scale against time. The curvilinear relationship is evidence that a mixture of

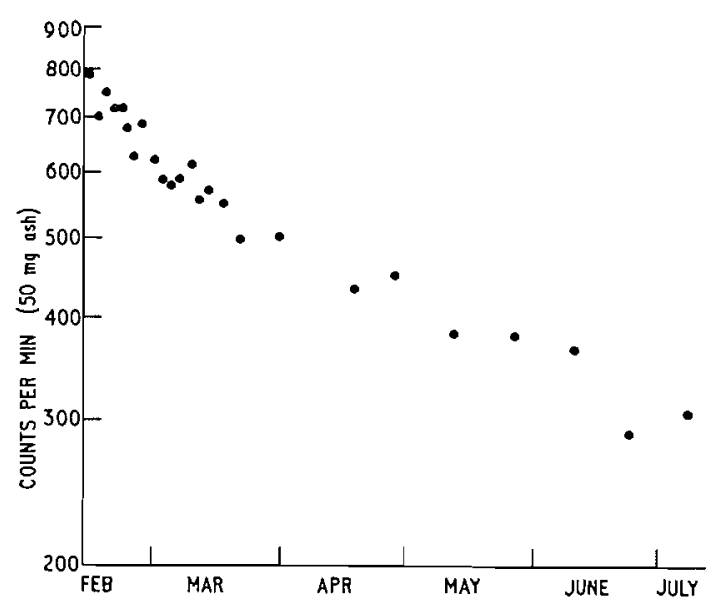

FIG. 1. Decay of radioactivity in a sample of Sphagnum papillosum ash. 
isotopes is involved, while the relatively rapid decay points to fall-out from thermonuclear explosions as their source. Although the accident at the Windscale plutonium factory took place in October 1957 not far from the area in which the present study was made, it does not appear to have been responsible for the high radioactivity of the Lake District vegetation, since Sphagnum papillosum samples collected as far away as North Wales and northwest Scotland yielded count rates just as high as those collected within a few miles of the Windscale factory.

The chief practical conclusion to be drawn from this work is that animals feeding on mosses and lichens may well exhibit high intakes of radioactive fall-out on this account. In this connection a few reindeer bones from Norway have been shown to contain markedly greater concentrations of radioactive strontium-90 than sheep bones from the same country (2).

1. Gorham, E. Accumulation of radioactive fall-out by plants in the English Lake District. Nature, 181, 1523-1524 (1958).

2. Hurdes, T. Norwegian Defence Res. Establ., Report No. IR-F-364. (Mimeographed, Oslo.)

3. Scott Russell, R. Deposition of strontiun-90 and its content in vegetation and in human diet in the United Kingdom. Nature, 182, 834-8.39 (1958).

ReCeIved November $25,1958$.

DEPARTMENT OF BOTANY,

UNIVERSITY OF TORONTO,

TORONTO, ONTARIO. 